\title{
MIĘDZYNARODOWE NIERÓWNOŚCI PŁACOWE W BRANŻACH USEUGOWYCH UNII EUROPEJSKIEJ
}

\begin{abstract}
W opracowaniu zaprezentowano wyniki badań dotyczące problematyki nierówności płacowych w układzie międzynarodowym. Dysproporcje w tym wymiarze uznaje się za jeden z podstawowych wyznaczników nierównomierności rozwojowych determinujących poziom dobrobytu społecznego. Idea powstawania i funkcjonowania ugrupowań integracyjnych, takich jak Unia Europejska, zakłada stopniową konwergencję społeczno-gospodarczą obejmującą również wyrównywanie się poziomu wynagrodzeń. W opracowaniu analizą objęto więc zróżnicowanie poziomu wynagrodzeń pomiędzy 28 państwami Unii Europejskiej. Diagnoza dysparytetów dotyczyła 12 sekcji działalności gospodarczej włączanych w ramy sektora usług. W krajach wysoko rozwiniętych sektor ten absorbuje największą część zasobów siły roboczej, a tym samym w znacznym stopniu determinuje rozkład wynagrodzeń. Celem analiz jest określenie skali dysproporcji płacowej w poszczególnych rodzajach działalności usługowej i wskazanie tych branży, które w największym stopniu kreują nierówności zarobków. Realizacja tego zadania opiera się na wykorzystaniu danych statystycznych udostępnianych przez Eurostat. Weryfikacja dysproporcji płacowych bazuje na takich miarach statystycznych, jak średnia, mediana, współczynnik zmienności, współczynnik asymetrii i współczynnik Giniego. Uzyskane wyniki wskazują, że relatywnie najmniejsze nierówności dotyczą branży nowoczesnych, wykorzystujących technologie ICT i w znacznym stopniu zliberalizowanych. Największe dysproporcje międzynarodowe dostrzegane są zaś w tradycyjnych dziedzinach usługowych i wynikają z trudności w przezwyciężeniu barier strukturalnych oraz opóźnień procesów integracyjnych. Dostrzega się ponadto współwystępowanie niskiego poziomu wynagrodzeń i znacznej skali dysproporcji międzynarodowych w ich wysokości, jak również relację odwrotną korzystną dla branży nowoczesnych.
\end{abstract}

Słowa kluczowe: nierówności płacowe, sektor usług, branże nowoczesne, branże tradycyjne, gospodarka oparta na wiedzy

\section{WPROWADZENIE}

Problematyka nierówności jest zagadnieniem niezmiernie złożonym, czego dowodzą różne wymiary, do których kwestie te są odnoszone. Nierówności odnajdywane są w płaszczyźnie społecznej, kulturowej, politycznej czy ekonomicznej. W sensie formalnym nierówności rozumiane są jako relacja, w której porównywane obiekty są niejednakowe i nierównoważne pod względem pewnego kryterium² ${ }^{2}$, którego specyfikacja prowadzi do określenia typu nierówności.

Akceptacja kryterium porównań prowadzi do wyboru wymiaru nierówności w kontekście szans, sytuacji i miar (wyników) ${ }^{3}$. Badania w zakresie nierówności ewoluują przy tym od

\footnotetext{
1 Dr Magdalena Cyrek, Katedra Mikroekonomii, Uniwersytet Rzeszowski, ul. M. Ćwiklińskiej 2, 35-601 Rzeszów, tel. 1787217 17, mcyrek@univ.rzeszow.pl

${ }^{2}$ A. Zachorowska-Mazurkiewicz, Istota nierówności w procesie rozwoju - podejście instytucjonalne, [w:] Wspótczesne wymiary nierówności w procesie globalizacji, red. E. Okoń-Horodyńska, A. ZachorowskaMazurkiewicz, Wydawnictwo Uniwersytetu Jagiellońskiego, Kraków 2011, s. 12.

${ }^{3}$ Ibidem, s. 20-21.
} 
koncentracji na efektach, co odzwierciedlają klasyczne prace Simona Kuznetsa, poprzez uwzględnienie problematyki dystrybucji zasobów i odniesienia się do nierówności szans i możliwości, co jako konieczne wskazywał między innymi Amartya Sen, do analiz nierówności w przebiegu procesów i różnych sposobów systemowego ujmowania kwestii nierówności.

Jak wskazują Jean-Yves Duclos i Abdelkrim Araar, analizy odnoszące się do problematyki dobrobytu i jego dystrybucji w społeczeństwie w klasycznym podejściu uwzględniają porównania ekonomicznego dobrobytu, określanego również jako standard życia, często utożsamianego z dochodem. Ujęcie to wywodzi się z tradycyjnej mikroekonomii, zakładającej że użyteczność stanowi podstawę zachowań i dobrobytu racjonalnych jednostek opierających swoje decyzje na systemie preferencji i ograniczeń zasobowych, technologicznych i cenowych. Współcześnie jednak w coraz większym zakresie jest przyjmowane drugie podejście, które w sposób wielowymiarowy uzupełnia jednowymiarowe rozumienie standardu życia. W jego ramach można wyróżnić dwa główne ujęcia: podstawowych potrzeb oraz możliwości. Pierwsze z nich koncentruje się na potrzebie uzyskania pewnych korzyści, które są zazwyczaj powiązane z koncepcją funkcjonalności rozwijaną przez Sena. Funkcjonalność może być rozumiana tutaj jako element tworzący dobrobyt. Druga alternatywa również wywodzi się od Sena, który stwierdza, że możliwość reprezentuje kombinacje funkcjonalności dostępnych dla jednostki odzwierciedlających zestaw jej wyborów. Istotna jest tutaj zdolność jednostki do funkcjonowania w społeczeństwie, a nie jedynie funkcjonalność osiągnięta przez tę osobę. Posiadanie zdolności osiągnięcia podstawowej funkcjonalności jest źródłem możliwości dobrego życia i uniknięcia ubóstwa lub deprywacji ${ }^{4}$.

W rozwijanych współcześnie koncepcjach coraz powszechniejsze staje się podejście zintegrowane do analizy nierówności, w którym podkreśla się wzajemne sprzężenia i współzależności między poszczególnymi sferami ich występowania, korespondującymi z wielowymiarowymi aspektami bytu ludzkiego ${ }^{5}$. W praktyce badań ekonomicznych najczęściej dokonywane są jednak porównania bazujące na rozkładzie dochodów, płac, majątku i różnych postaci zasobów (w tym kapitału ludzkiego), a także konsumpcji i wydatków w ujęciu ich bieżącego stanu i możliwości pozyskania.

Technicznie analiza dobrobytu wymaga uwzględnienia dwóch aspektów tego zagadnienia: skali, przybliżanej przez takie miary jak średnia czy mediana, oraz rozkładu, określanego przez miary nierówności ${ }^{6}$. Wśród najczęściej wykorzystywanych miar nierówności wyróżnia się: pozycyjne miary nierówności społecznych (oparte na percentylach, decylach, kwintylach, kwartylach itp.), indeks McLoone’a (oparty na medianie), współczynnik Giniego (oparty na krzywej Lorenza) czy indeks Theila, a także różnorodnie określane progi ubóstwa, stanowiące podstawę porównań odsetka osób w najtrudniejszej sytuacji ${ }^{7}$

\footnotetext{
${ }^{4} \mathrm{~J}-\mathrm{Y}$. Duclos, A. Araar, Poverty and equity: measurement, policy and estimation with DAD, [w:] Economic studies in inequality, social exclusion and well-being, red. J. Silber, t. 2, Springer, International Development Research Centre, New York, Ottawa 2006, s. 3, 5, 7.

${ }^{5}$ Na konieczność takiego podejścia zwraca uwagę między innymi Michał Gabriel Woźniak. Por. M.G. Woźniak, Fundamentalne kwestie spójności spoteczno-ekonomicznej w ujęciu holistycznym. Teoria i praktyka, [w:] Nierówności społeczne a wzrost gospodarczy w kontekście spójności spoteczno-ekonomicznej, red. M.G. Woźniak, Wydawnictwo Uniwersytetu Rzeszowskiego, Rzeszów 2008, z. 13, s. 18.

${ }^{6}$ J. Foster, S. Seth, M. Lokshin, Z. Sajaia, A Unified Approach to Measuring Poverty and Inequality. Theory and Practice, The World Bank, Washington, D.C. 2013, s. 3.

${ }^{7}$ P. Jabkowski, Miary nierówności społecznych - podstawy metodologiczne, [w:] Spór o spoteczne znaczenie społecznych nierówności, red. K. Podemski, Uniwersytet im. Adama Mickiewicza w Poznaniu, Seria „Socjologia” nr 65, Wydawnictwo Naukowe UAM, Poznań 2009, s. 32-39; K. Podemski, Nierówności ekonomiczne
} 
Jak wskazuje Prakash Loungani, nierówności mogą występować wewnątrz krajów, między poszczególnymi krajami, jak również w ujęciu globalnym ${ }^{8}$, co jest warunkowane określeniem obiektów rozważanej relacji. Analiza nierówności prowadzona jest więc na poziomie mikro, mezo lub makro9 . Wymiary te pozostają ze sobą w ścisłym związku, choć często rezultaty analiz prowadzonych w każdej z tych płaszczyzn prowadzą do odmiennych wniosków.

Charakter nierówności pozwolił ponadto Jean-Paulowi Fitoussiemu i Pierre'owi Rosanvallonowi na rozróżnienie tradycyjnych nierówności strukturalnych oraz nierówności dynamicznych, które pojawiają się $\mathrm{w}$ ramach dotychczas jednorodnej grupy ${ }^{10}$. Na uwagę badaczy zasługują szczególnie nierówności dynamiczne, które pojawiają się w związku z nieustannymi zmianami społecznymi, technologicznymi, gospodarczymi czy politycznymi. Najczęściej źródła i efekty tych przemian nie są rozmieszczone symetrycznie w ramach dotychczasowych struktur społeczno-gospodarczych i przyczyniają się do wzrostu nierównomierności.

Z punktu widzenia oceny zjawiska nierówności szczególnie istotne staje się ich wartościowanie uwzględniające akceptowaną aksjologię. Marek Bugdol zwraca uwagę na możliwość występowania nierówności niesprawiedliwych i niemoralnych, które spowodowane są krzywdzącym podziałem dóbr, stwarzaniem zróżnicowanych możliwości rozwoju czy selektywnym traktowaniem pracowników oraz nierówności sprawiedliwych, a więc pożądanych i naturalnych, które wynikają z autentycznego zaangażowania pracowników i rzeczywistego wkładu pracy $^{11}$. Michał Gabriel Woźniak wyróżnia analogicznie nierówności frustrujące i aktywizują$\mathrm{ce}^{12}$, mające odmienny wpływ na zachowania jednostek i grup społecznych.

W niniejszym opracowaniu badaniom poddaje się nierówności w poziomie wynagrodzeń obserwowane w 28 państwach członkowskich Unii Europejskiej. Podjęcie tego aspektu badań nad nierównościami w ramach Wspólnoty, choć uwzględnia jedynie jeden z wymiarów złożonej problematyki, warunkowane jest niewątpliwym znaczeniem kwestii wynagrodzeń zarówno w obszarze ekonomicznym, jak i społecznym. Płace stanowią bowiem podstawowy element determinujący dochody ludności i bezpośrednio przesądzają o standardzie życia szerokich grup społeczeństwa. Choć bezpośrednio odzwierciedlają rozkład efektów działalności gospodarczej, to jednak są również symptomem nierówności w dostępie do pracy i zarobkowania oraz sprawności przebiegu procesów produkcyjnych i możliwości efektywnego wykorzystania zasobów. Ich kształtowanie się decyduje ponadto o wypełnianiu unijnych celów spójnościowych.

Badania dla lat 2004-2011 przeprowadzone przez Stanisława Wydymusa wskazują niestety, że choć poziom średnich miesięcznych wynagrodzeń wykazywał coraz mniejsze zróżnicowanie w UE, to jednak rosła ich asymetria związana z szybszym rozwojem krajów najwyżej

$w$ europejskich krajach postkomunistycznych z globalnej perspektywy - wybrane zagadnienia, [w:] Spór o spoteczne..., s. 54-55.

${ }^{8}$ A. Zachorowska-Mazurkiewicz, Istota nierówności w procesie rozwoju - podejście instytucjonalne, [w:] Wspótczesne wymiary nierówności $w$ procesie globalizacji, red. E. Okoń-Horodyńska, A. ZachorowskaMazurkiewicz, Wydawnictwo Uniwersytetu Jagiellońskiego, Kraków 2011, s. 16.

${ }^{9}$ M. Bugdol, Zarządzanie międzynarodowe a problem nierówności spoteczno-ekonomicznych, [w:] Wspótczesne wymiary nierówności..., s. 102.

${ }^{10}$ A. Zachorowska-Mazurkiewicz, op. cit., s. 15.

${ }^{11}$ M. Bugdol, op. cit., s. 102.

${ }^{12}$ Na taki charakter nierówności zwraca uwagę Michał Gabriel Woźniak w ramach szerokiego programu badawczego nierówności społeczne - wzrost gospodarczy - modernizacja. Krótką prezentację tego programu zawarto w: Ł. Jabłoński, O nowym programie badawczym nad nierównościami społeczno-ekonomicznymi [w:] Nierówności społeczne a wzrost gospodarczy..., Rzeszów 2013, s. 9. 
rozwiniętych. Polska zmniejszała swój dystans względem większości państw, utrzymując jednak wyraźnie niższy poziom wynagrodzeń. Ponadto autor ten dowodzi, że płace w Polsce są zdecydowanie zaniżone w stosunku do skali zróżnicowań produktu krajowego brutto (PKB) jako miary efektywności i makrowydajności kapitału ludzkiego. Obserwowany wzrost tych dysproporcji świadczy o nierealizowaniu głównego celu integracyjnego, jakim jest wyrównywanie poziomu życia we wszystkich krajach $\mathrm{UE}^{13}$.

W artykule zróżnicowanie zarobków pomiędzy analizowanymi krajami oceniono w odniesieniu do absorbującego największą część siły roboczej sektora usług oraz poszczególnych branż usługowych. Sektor usług został ujęty jako działalność realizowana w ramach sekcji G-S (z wyłączeniem sekcji O) według klasyfikacji NACE Rev. 2.2. Jak wskazuje się w innych badaniach ${ }^{14}$, sektor ten nie tylko angażuje najwięcej osób pracujących i odpowiada za największą część wytworzonej produkcji w krajach UE, ale również wykazuje korzystne współzależności z kwestiami społecznymi, takimi jak ubóstwo i wykluczenie. Szczególnie wysokie zatrudnienie w nowoczesnych wiedzochłonnych branżach usługowych współwystępuje z minimalizacją wewnętrznych nierówności dochodowych w państwach UE.

$\mathrm{W}$ prezentowanych $\mathrm{w}$ tekście badaniach postawiono natomiast pytanie, czy pomiędzy krajami ugrupowania występują różnice rozkładu wynagrodzeń uzyskiwanych w ramach poszczególnych branży sektora usług. Celem stało się określenie skali nierówności płacowych generowanych przez różne rodzaje działalności usługowej oraz zidentyfikowanie tych dziedzin, które w największym stopniu różnicują państwa członkowskie, a więc odpowiadają za międzynarodowe nierówności płacowe. Szczególnie interesujące jest określenie, czy różnice te w większym stopniu dotyczą tradycyjnych, czy nowoczesnych branży usługowych, a więc czy wynikają z trudności w przezwyciężeniu zapóźnień strukturalnych, czy też wiążą się z nowymi procesami polaryzacji międzynarodowej związanymi z rozwojem gospodarki opartej na wiedzy. Należy przy tym pamiętać, że często zatrudnienie na niskopłatnych i niewymagających kwalifikacji stanowiskach jest pułapką zarówno z punktu widzenia jednostki, jak i całej gospodarki narodowej. Co więcej, ograniczanie takich nierówności poprzez mechanizmy redystrybucyjne może prowadzić do wzrostu kosztów pracy i bezrobocia, co podważa ich skuteczność ${ }^{15}$.

Do realizacji postawionego w opracowaniu zadania wykorzystano kilka wskaźników opisujących rozkład poziomu średnich rocznych wynagrodzeń w państwach UE, takich jak wartość średnia i mediana, wartość maksymalna i minimalna oraz rozstęp między nimi, współczynnik zmienności, współczynnik asymetrii oraz współczynnik Giniego. Ten ostatni został obliczony według wzoru ${ }^{16}$ :

$$
I_{G i n i}(x)=\frac{1}{2 N^{2} * W_{A}(x)} \sum_{n=1}^{N} \sum_{n^{\prime}=1}^{N}\left|x_{n}-x_{n^{\prime}}\right|
$$

gdzie:

\footnotetext{
${ }^{13}$ S. Wydymus, Rozwój gospodarczy a poziom wynagrodzeń w krajach Unii Europejskiej - analiza taksonomiczna, „Zeszyty Naukowe Uniwersytetu Szczecińskiego” nr 756: Finanse, rynki finansowe, ubezpieczenia, nr 57: Miejsce Polski w gospodarce światowej, Szczecin 2013, s. 638-644.

${ }^{14}$ M. Cyrek, Struktura zatrudnienia a nierówności i zagrożenia spoteczne w gospodarkach UE, „Ekonomia Economics" 2/23 (2013), s. 49-63.

${ }^{15}$ G. Mazurkiewicz, Edukacja w czasach globalizacji: niespetniona obietnica likwidacji nierówności, [w:] Wspótczesne wymiary nierówności..., s. 84.

${ }^{16}$ J. Foster, S. Seth, M. Lokshin, Z. Sajaia, A Unified Approach to Measuring Poverty and Inequality. Theory and Practice, The World Bank, Washington, D.C. 2013, s. 94.
} 
$\mathrm{x}_{\mathrm{n}}$ - wartość zmiennej dla obiektu $\mathrm{n}, \mathrm{n}=1, \ldots, \mathrm{N}$,

$\mathrm{W}_{\mathrm{A}}(\mathrm{x})$ - średnia wartość $\mathrm{x}$ dla $\mathrm{N}$ obiektów.

W analizach wykorzystano dane udostępniane przez Eurostat prezentujące poziom przeciętnych rocznych wynagrodzeń w euro w 2010 roku według rodzajów działalności w podmiotach o liczbie pracujących 10 i więcej osób w 28 państwach UE ${ }^{17}$. Były to najbardziej aktualne statystyki dostępne w ramach systematycznie prowadzonego badania struktury wynagrodzeń.

\section{ANALIZA ZRÓŻNICOWAŃ PŁACOWYCH W DZIAŁALNOŚCI USŁUGOWEJ}

Absorbujący współcześnie największą część siły roboczej sektor usług jest obszarem o niezwykłej różnorodności rodzajów prowadzonej działalności gospodarczej. Obejmuje zarówno aktywności o charakterze tradycyjnym, niewymagającym specjalistycznej wiedzy i umiejętności, jak i takie dziedziny, w których koncentruje się najnowsza myśl naukowotechnologiczna. Te specyfiki są jednym z istotnych czynników warunkujących zróżnicowanie płacowe obserwowane pomiędzy poszczególnymi branżami usługowymi. Jednocześnie zróżnicowanie poziomu zaawansowania zmian strukturalnych pomiędzy porównywanymi państwami może generować dysproporcje $\mathrm{w}$ opłacaniu pracy zaangażowanej w sektorze usług. Różnice te wydają się narastać w sytuacji wzrostu autarkii poszczególnych gospodarek, swoboda przepływu czynników wytwórczych zaś, w tym ich nowoczesnych form w postaci informacji i wiedzy, powinna stopniowo zróżnicowanie to niwelować. Zaawansowanie procesów integracyjnych w wymiarze poszczególnych rodzajów działalności może więc warunkować skalę nierówności płacowych pomiędzy państwami UE.

W całym sektorze usług w 28 państwach członkowskich Unii Europejskiej przeciętne roczne wynagrodzenie w 2010 roku w przedsiębiorstwach zatrudniających 10 i więcej osób wynosiło 25,8 tys. euro. Różnica płacowa pomiędzy Bułgarią, gdzie płace te były najniższe, a Luksemburgiem, w którym osiągnięto wartość maksymalną zarobków, wynosiła ponad 50 tys. euro. Zmienność uzyskiwanych wynagrodzeń pomiędzy poszczególnymi gospodarkami znalazła się na poziomie około $58 \%$. W połowie państw uzyskiwano wynagrodzenie w usługach nieprzekraczające 26 tys. euro. Odnotowano przy tym niewielką prawostronną asymetrię rozkładu wynagrodzeń wokół średniej dla 28 krajów. Nierówności w rozkładzie przeciętnych wynagrodzeń pomiędzy gospodarkami UE mierzone współczynnikiem Giniego osiągnęły poziom 0,3236 (rys. 1 ).

\footnotetext{
17 Eurostat [earn_ses10_26], http://epp.eurostat.ec.europa.eu/portal/page/portal/statistics/search_database (dostęp: 13.10.2013).
} 
Rys. 1. Poziom wynagrodzeń w sektorze usług jako odsetek poziomu przeciętnego w UE-28 w 2010 roku

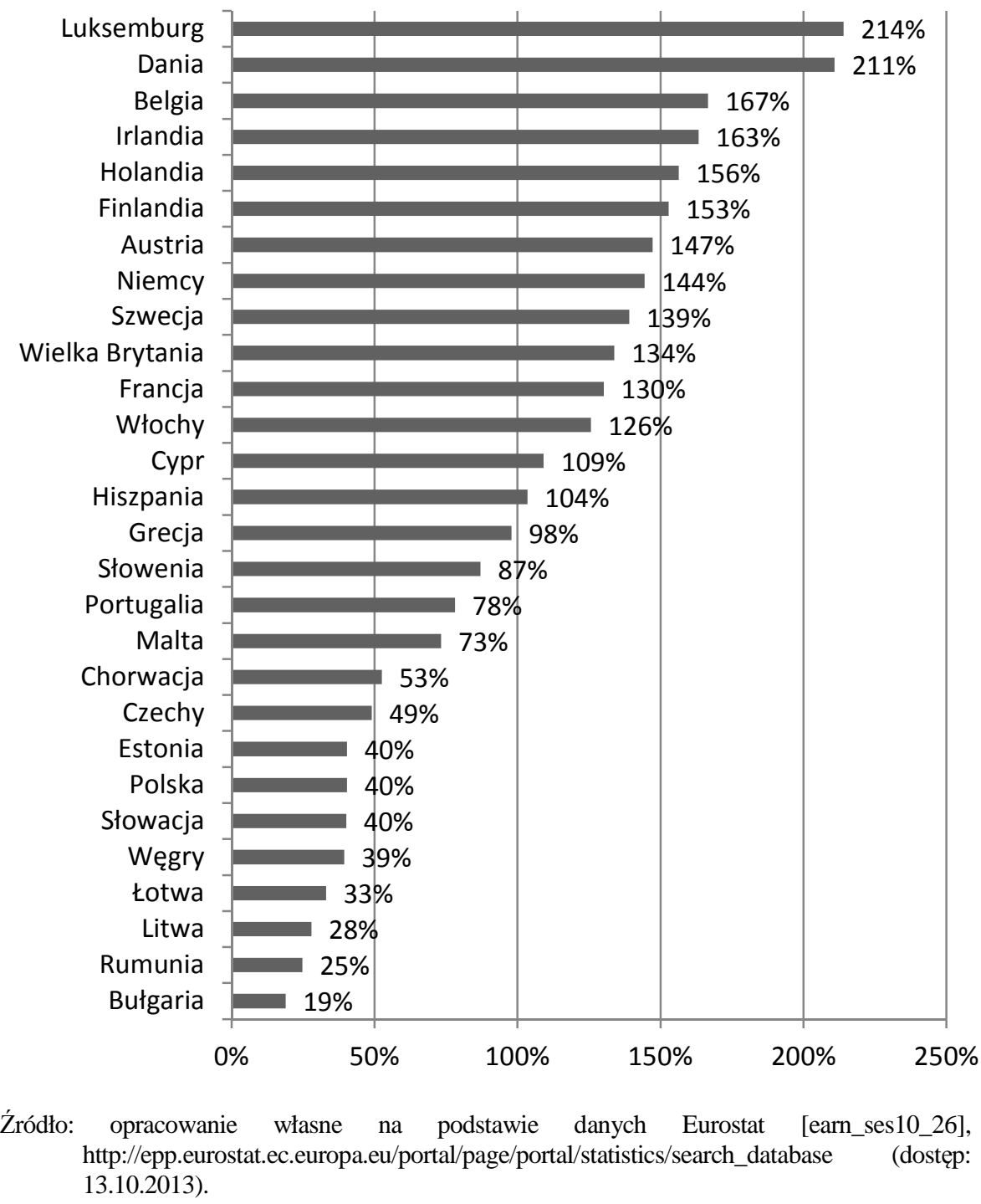

W poszczególnych branżach usługowych międzynarodowe różnice płacowe wykazywały jednak wiele odmienności, co obrazują zarówno statystyki prezentujące ich średnie poziomy i odchylenia od nich (rys. 2), jak i wartości mediany i pozostałe wielkości kwartylowe (rys. 3) oraz wartości współczynnika Giniego (rys. 4). Szczegółowe wartości statystyk płacowych zaprezentowano w tabeli 1. 
Rys. 2. Poziom średnich wynagrodzeń i jego zróżnicowanie w branżach sektora usług w krajach UE-28 w 2010 roku

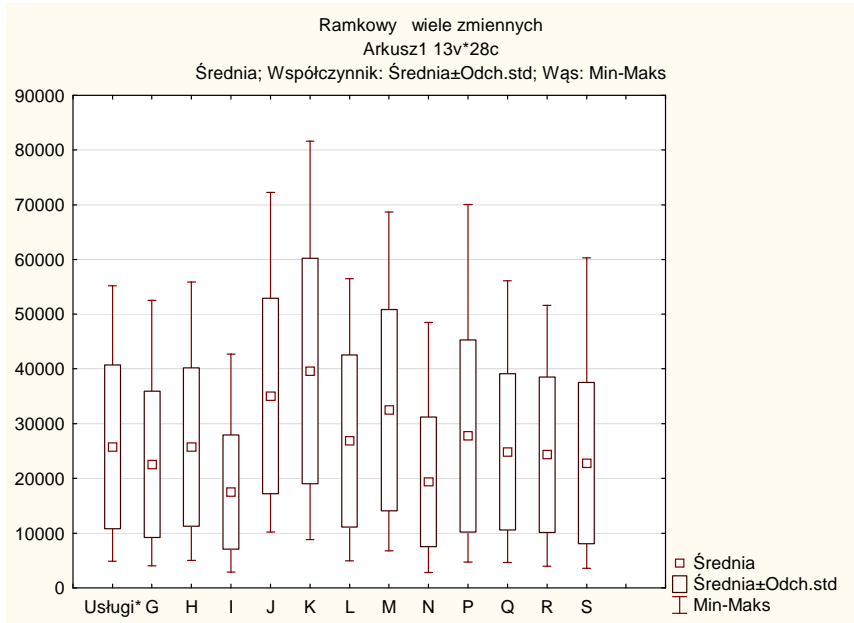

Usługi* - sektor usług rozumiany jako sekcje G-S (z wyłączeniem O) według NACE Rev. 2.2

Źródło: opracowanie własne na podstawie danych Eurostat [earn_ses10_26], http://epp.eurostat.ec.europa.eu/portal/page/portal/statistics/search_database (dostęp: 13.10.2013).

Rys. 3. Mediana i pozostałe kwartyle wynagrodzeń w branżach sektora usług w krajach UE-28 w 2010 roku

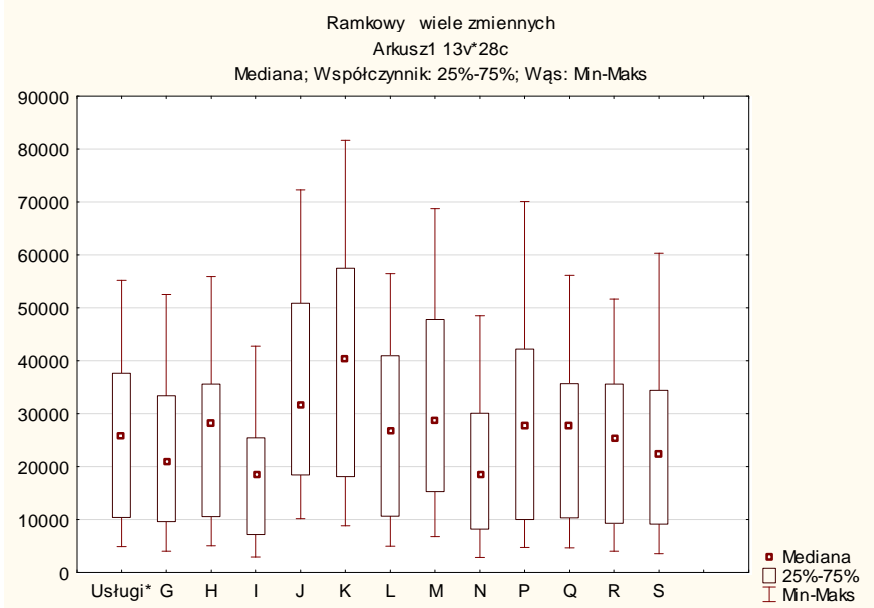

Usługi* - sektor usług rozumiany jako sekcje G-S (z wyłączeniem O) według NACE Rev. 2.2

Źródło: opracowanie własne na podstawie danych Eurostat [earn_ses10_26], http://epp.eurostat.ec.europa.eu/portal/page/portal/statistics/search_database (dostęp: 13.10.2013). 
Rys. 4. Współczynnik Giniego w odniesieniu do płac w branżach sektora usług w krajach UE-28 w 2010 roku

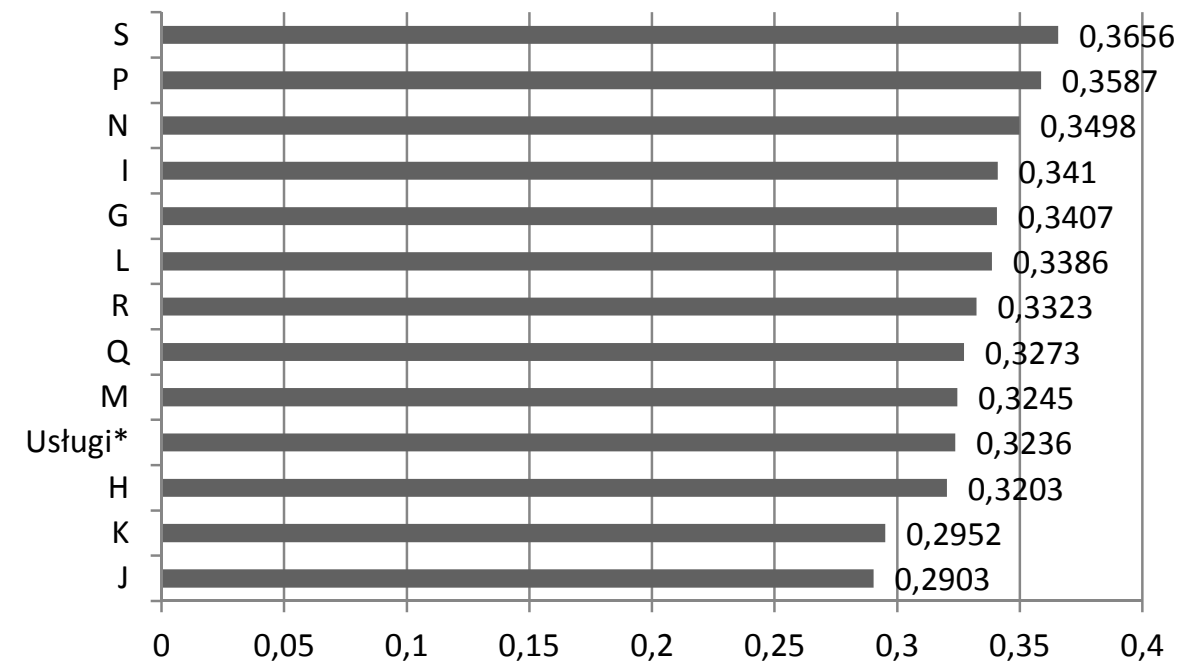

Usługi* - sektor usług rozumiany jako sekcje G-S (z wyłączeniem O) według NACE Rev. 2.2

Źródło: opracowanie własne na podstawie danych Eurostat [earn_ses10_26], http://epp.eurostat.ec.europa.eu/portal/page/portal/statistics/search_database (dostęp: 13.10.2013).

Tabela 1. Statystyki poziomu wynagrodzeń w sektorze usług i jego branżach w UE-28 w 2010 roku

\begin{tabular}{|l|c|c|c|c|c|c|c|c|c|c|c|c|c|}
\hline & Usługi* & $\mathrm{G}$ & $\mathrm{H}$ & $\mathrm{I}$ & $\mathrm{J}$ & $\mathrm{K}$ & $\mathrm{L}$ & $\mathrm{M}$ & $\mathrm{N}$ & $\mathrm{P}$ & $\mathrm{Q}$ & $\mathrm{R}$ & $\mathrm{S}$ \\
\hline Średnia (€) & 25789,25 & 22562,89 & 25720,57 & 17519,5 & 35047,5 & 39599,25 & 26849,46 & 32497,39 & 19370,79 & 27761,68 & 24850,25 & 24343,18 & 22805,82 \\
\hline $\begin{array}{l}\text { Odchylenie } \\
\text { standardowe (€) }\end{array}$ & 14952,45 & 13373,15 & 14462,61 & 10451,02 & 17814,87 & 20595,18 & 15721,8 & 18382,18 & 11858,09 & 17575,32 & 14281,35 & 14218,1 & 14705,89 \\
\hline $\begin{array}{l}\text { Współczynnik } \\
\text { zmienności (\%) }\end{array}$ & 57,98 & 59,27 & 56,23 & 59,65 & 50,83 & 52,01 & 58,55 & 56,57 & 61,22 & 63,31 & 57,47 & 58,41 & 64,48 \\
\hline Minimum (€) & 4890 & 4021 & 5036 & 2862 & 10176 & 8820 & 4921 & 6764 & 2830 & 4733 & 4660 & 3988 & 3579 \\
\hline Maksimum (€) & 55208 & 52486 & 55857 & 42688 & 72228 & 81615 & 56446 & 68697 & 48494 & 70031 & 56088 & 51609 & 60326 \\
\hline \begin{tabular}{l} 
Rozstęp (€) \\
\hline 50318
\end{tabular} & 48465 & 50821 & 39826 & 62052 & 72795 & 51525 & 61933 & 45664 & 65298 & 51428 & 47621 & 56747 \\
\hline Mediana (€) & 25966,5 & 20792 & 28313 & 18723,5 & 31466 & 40480 & 26574 & 28802,5 & 18431 & 27650 & 27588,5 & 25235 & 22210 \\
\hline $\begin{array}{l}\text { Współczynnik } \\
\text { asymetrii }\end{array}$ & 0,2648 & 0,3626 & 0,1180 & 0,3661 & 0,2616 & 0,2043 & 0,0902 & 0,3482 & 0,4924 & 0,4260 & 0,2171 & 0,0983 & 0,5434 \\
\hline $\begin{array}{l}\text { Współczynnik } \\
\text { Giniego }\end{array}$ & 0,3236 & 0,3407 & 0,3203 & 0,3410 & 0,2903 & 0,2952 & 0,3386 & 0,3245 & 0,3498 & 0,3587 & 0,3273 & 0,3323 & 0,3656 \\
\hline
\end{tabular}

Usługi* - sektor usług rozumiany jako sekcje G-S (z wyłączeniem O) według NACE Rev. 2.2

Źródło: opracowanie własne na podstawie danych Eurostat [earn_ses10_26], http://epp.eurostat.ec.europa.eu/portal/page/portal/statistics/search_database, dostęp: 13.10.2013. 
Najwyższy poziom przeciętnych rocznych wynagrodzeń odnotowano w działalności z zakresu finansów i ubezpieczeń. Były one o ponad połowę wyższe niż średnia dla całego sektora usług. Jednocześnie płace $\mathrm{w}$ tej sekcji charakteryzowały się największym rozstępem, gdyż różnice sięgały 72,8 tys. euro, a minimum i maksimum ponownie zaobserwowano odpowiednio w Bułgarii i Luksemburgu. Pomimo tak dużych dysproporcji w ujęciu wartościowym, względna zmienność zarobków wynosiła jedynie 52\%. Skala nierówności mierzonych wspótczynnikiem Giniego była również relatywnie niska i wynosiła 0,2952. Przedstawione statystyki dowodzą więc, że sfera finansów i ubezpieczeń w UE była raczej obszarem minimalizującym dysproporcje wynagrodzeń w ujęciu międzynarodowym. Branża ta cechuje się bardzo silnymi powiązaniami i współzależnościami między państwami, a działające w jej ramach przedsiębiorstwa to często wielkie korporacje i współzależne grupy kapitałowe. Znaczny zakres swobody przepływów na rynkach finansowych i integracja działalności w skali UE warunkować mogą stosunkowo niewielkie nierówności w obszarze wynagrodzeń.

Relatywnie wysokie zarobki odnotowano również w sekcji J - Informacja i komunikacja, gdzie stanowiły około $136 \%$ poziomu dla sektora usług. W branży tej zaobserwowano ponadto najniższy względny poziom zmienności (51\%) i minimalną wartość współczynnika Giniego $(0,2903)$. Działalność ta charakteryzuje się wysokim poziomem współzależności międzynarodowej, a powiązania te umożliwiane są przez szerokie wykorzystanie technologii informacyjno-komunikacyjnych (ICT). Taka specyfika branży w efekcie skutkuje zacieraniem się różnic płacowych pomiędzy poszczególnymi państwami UE. Jej wiedzochłonność i zaawansowanie technologiczne warunkują wzrost spójności międzynarodowej. Te ogólne zależności nie zmieniają jednak faktu, że pomiędzy poszczególnymi gospodarkami wciąż obserwowane są znaczne rozpiętości w wysokości płac sięgające 62 tys. euro rocznie. Wynagrodzenia w 2010 roku okazały się najniższe w Bułgarii, najwyższe zaś w Danii.

Wysokie wynagrodzenia otrzymują również pracujący w nowoczesnej sekcji M - Usługi profesjonalne, naukowe i techniczne. Jednak dysproporcje wynagrodzeń pomiędzy państwami są w tej sferze już większe i mogą być scharakteryzowane 57-procentowym współczynnikiem zmienności oraz współczynnikiem Giniego na poziomie 0,3245 , a więc powyżej wartości dla sektora usług ogółem. Sytuacja taka wynikać może z relatywnie mniejszej mobilności pracy i uosobionego w niej kapitału ludzkiego, ograniczającej wyrównujące efekty integracyjne. Jednocześnie podkreślić należy, że działalność w tym obszarze w sposób szczególny jest warunkowana zasobami wiedzy ludzkiej i specyficznymi umiejętnościami pracujących. Rozwój usług profesjonalnych, naukowych i technicznych często przesądza o możliwościach rozwoju społeczno-gospodarczego opartego na czynnikach endogenicznych, które pozostają znacznie zróżnicowane w ujęciu międzynarodowym.

Najniższe poziomy wynagrodzeń wśród branż usługowych w UE odnotowano natomiast w działalności z zakresu zakwaterowania i gastronomii. Średni ich poziom wyniósł 17,5 tys. euro rocznie i stanowił zaledwie $68 \%$ przeciętnego poziomu dla całego sektora usług. Minimalny poziom zarobków w tej branży odnotowano w Bułgarii, najwyższy zaś w Danii. Choć rozpiętość wynagrodzeń w tej sekcji w UE to jedynie około 40 tys. euro i jest to najniższa różnica wartościowa wśród wszystkich branż usługowych, to względna zmienność okazuje się wysoka i sięga $60 \%$. Znaczne są również nierównomierności w rozkładzie wynagrodzeń, co odzwierciedla współczynnik Giniego na poziomie 0,3410 . Niewątpliwie związane jest to z ogólnym poziomem zamożności społeczeństw, który warunkuje popyt na wiele usług, $w$ tym usługi turystyczne i zagospodarowujące czas wolny w znacznym stopniu determinujące działalność hotelarską i restauracyjną. Innym istotnym czynnikiem wpływającym na różnice płacowe $\mathrm{w}$ tej branży mogą być także stan rozwoju infrastruktury technicznej oraz specyfika 
zaangażowanej siły roboczej, która w działalności gastronomiczno-hotelarskiej zazwyczaj nie dysponuje wysokim poziomem kapitału ludzkiego.

Niskie przeciętne zarobki odnotowano również w sekcji N - Usługi administrowania i wspierające, gdzie stanowiły około $75 \%$ poziomu odnotowanego w sektorze usług. Dodatkowo w branży tej mediana rocznych wynagrodzeń była najniższa. Niski poziom wynagrodzeń współistniał przy tym z wysoką względną zmiennością (61\%) i nierównomiernością rozkładu płac (współczynnik Giniego wyniósł 0,3498). W tej branży również pracujący cechują się przeciętnie niskim poziomem wykształcenia i umiejętności profesjonalnych, co może warunkować skalę dysproporcji zarobkowych.

Podobna jest specyfika wynagrodzeń w sekcjach $\mathrm{G}$ - Handel i naprawy oraz S - Pozostała działalność usługowa. Tutaj również poziom płac był relatywnie niski i wynosił odpowiednio $87 \%$ i $88 \%$ poziomu dla całego sektora usług. W obu tych branżach wysoka była względna zmienność zarobków, a ich rozkład w państwach UE stosunkowo nierównomierny. Pozostała działalność usługowa odznaczyła się przy tym najwyższym poziomem zarówno współczynnika zmienności (64\%), jak i współczynnika Giniego (0,3656). Niski poziom kapitału ludzkiego zaangażowanego w tych branżach można uznać za specyfikę warunkującą tak znaczne dysproporcje międzynarodowe w poziomie zarobków.

Specyficzna jest również sytuacja w zakresie wynagrodzeń w obszarze edukacji. Poziom przeciętnych zarobków pozostaje na poziomie nieznacznie powyżej średniego dla całego sektora usług. Jednocześnie odnotowuje się dość znaczne dysproporcje płacowe pomiędzy poszczególnymi państwami. Rozstęp pomiędzy wartością minimalną (Bułgaria) i maksymalną (Luksemburg) przekracza 65 tys. euro, a względna zmienność to aż 63\%. Wysoką nierównomierność rozkładu płac w państwach UE potwierdza stosunkowo wysoki współczynnik Giniego $(0,3587)$. Charakterystyka ta niewątpliwie determinowana jest zamożnością społeczeństw, decydujących się w różnym zakresie na dokonywanie inwestycji w budowanie kapitału ludzkiego, zarówno w ramach działań indywidualnych, jak i poprzez wsparcie ze sfery publicznej.

\section{ZAKOŃCZENIE}

Przeprowadzone analizy międzynarodowych nierówności płacowych w poszczególnych branżach sektora usług pozwalają wnioskować o mniejszym zróżnicowaniu w odniesieniu do dziedzin nowoczesnych, bazujących na przepływach wiedzy i informacji możliwych dzięki rozwojowi technologii ICT i procesom liberalizacji. W branżach, takich jak finanse czy informacja i komunikacja, nie tylko relatywna zmienność zarobków okazała się niewielka, ale i poziom wynagrodzeń stosunkowo wysoki. Są to więc dziedziny szczególnie atrakcyjne dla potencjalnych pracowników. Natomiast w innych nowoczesnych dziedzinach sektora usług, takich jak działalność profesjonalna, naukowa i techniczna czy kreujący kapitał ludzki obszar edukacji, międzynarodowe nierówności płacowe były wyższe. Może to wynikać z relatywnie mniejszej mobilności czynnika ludzkiego, który jest podstawą tych form aktywności usługowej. W tradycyjnych branżach usługowych: zakwaterowaniu i gastronomii, handlu i naprawach, usługach wspierających i pozostałych zaobserwowano z kolei współwystępowanie niskiego poziomu zarobków i znaczących dysproporcji płac pomiędzy poszczególnymi krajami. Spostrzeżenia te skłaniają do wniosku, że nierówności płacowe w branżach usługowych wynikają przede wszystkich z trudności dostosowań strukturalnych w kierunku nowoczesnej gospodarki opartej na wiedzy. 


\section{LITERATURA}

[1] Bugdol M., Zarządzanie międzynarodowe a problem nierówności spoteczno-ekonomicznych, [w:] Wspótczesne wymiary nierówności w procesie globalizacji, red. E. Okoń-Horodyńska, A. Zachorowska-Mazurkiewicz, Wydawnictwo Uniwersytetu Jagiellońskiego, Kraków 2011.

[2] Cyrek M., Struktura zatrudnienia a nierówności i zagrożenia społeczne w gospodarkach UE, „Ekonomia Economics” 2/23 (2013).

[3] Duclos J.-Y., Araar A., Poverty and equity: measurement, policy and estimation with DAD, [w:] Economic studies in inequality, social exclusion and well-being, red. J. Silber, t. 2, Springer, International Development Research Centre, New York, Ottawa 2006.

[4] Eurostat [earn_ses10_26], http://epp.eurostat.ec.europa.eu/portal/page/portal/statistics/ search_database (dostęp: 13.10.2013).

[5] Foster J., Seth S., Lokshin M., Sajaia Z., A Unified Approach to Measuring Poverty and Inequality. Theory and Practice, The World Bank, Washington, D.C. 2013.

[6] Jabkowski P., Miary nierówności społecznych - podstawy metodologiczne, [w:] Spór o spoteczne znaczenie społecznych nierówności, red. K. Podemski, Uniwersytet im. Adama Mickiewicza w Poznaniu, Seria „Socjologia” nr 65, Wydawnictwo Naukowe UAM, Poznań 2009.

[7] Jabłoński Ł., O nowym programie badawczym nad nierównościami społeczno-ekonomicznymi, [w:] Nierówności spoteczne a wzrost gospodarczy. Kryzys finansów publicznych - przyczyny, implikacje, perspektywy spójności społeczno-ekonomicznej, red. M.G. Woźniak, z. 31, Wydawnictwo Uniwersytetu Rzeszowskiego, Rzeszów 2013.

[8] Mazurkiewicz G., Edukacja w czasach globalizacji: niespetniona obietnica likwidacji nierówności, [w:] Wspótczesne wymiary nierówności w procesie globalizacji, red. E. OkońHorodyńska, A. Zachorowska-Mazurkiewicz, Wydawnictwo Uniwersytetu Jagiellońskiego, Kraków 2011.

[9] Podemski K., Nierówności ekonomiczne w europejskich krajach postkomunistycznych z globalnej perspektywy - wybrane zagadnienia, [w:] Spór o spoteczne znaczenie spotecznych nierówności, red. K. Podemski, Uniwersytet im. Adama Mickiewicza w Poznaniu, Seria „Socjologia" nr 65, Wydawnictwo Naukowe UAM, Poznań 2009.

[10] Woźniak M.G., Fundamentalne kwestie spójności spoteczno-ekonomicznej w ujęciu holistycznym. Teoria i praktyka, [w:] Nierówności spoteczne a wzrost gospodarczy w kontekście spójności społeczno-ekonomicznej, red. M.G. Woźniak, z. 13, Wydawnictwo Uniwersytetu Rzeszowskiego, Rzeszów 2008.

[11] Wydymus S., Rozwój gospodarczy a poziom wynagrodzeń w krajach Unii Europejskiej analiza taksonomiczna, „Zeszyty Naukowe Uniwersytetu Szczecińskiego” nr 756; Finanse, rynki finansowe, ubezpieczenia, nr 57: Miejsce Polski w gospodarce światowej, Szczecin 2013.

[12] Zachorowska-Mazurkiewicz A., Istota nierówności w procesie rozwoju - podejście instytucjonalne, [w:] Wspótczesne wymiary nierówności w procesie globalizacji, red. E. OkońHorodyńska, A. Zachorowska-Mazurkiewicz, Wydawnictwo Uniwersytetu Jagiellońskiego, Kraków 2011.

\section{INTERNATIONAL EARNING INEQUALITIES IN SERVICE ACTIVITIES IN EUROPEAN UNION}

Some results of research concerning wage inequality in an international dimension are presented in the study. Such disproportion is concerned as one of main indices of developmental disparities that determine social welfare. An idea of creation and functioning of integration areas, such as European Union, assumes existence of socio-economic convergence which also covers equalization of remunerations' level. The analysis in the study covered, therefore, disproportions in earnings between $28 \mathrm{EU}$ countries. A diagnosis of the disparity concerned 12 sections of eco- 
nomic activity that constitute a service sector. In highly developed countries the sector absorbs a main part of human resources and thus essentially determines distribution of earnings. The aim of the analyses is to specify a scale of the earning disparities and to indicate the branches which to the biggest extend create the inequality. To realize the task there were used statistical data extracted from Eurostat database. To verify the earning disparities there were used measures such as a mean, a median, indicator of variability, indicator of asymmetry, Gini coefficient. The results indicate that relatively the smallest inequality concerns the most modern branches, that use ICT and are highly liberalized. The biggest international disparities are observed in traditional service branches and result from difficulties in overcoming structural barriers and delays in integration processes. Moreover, a low level of remunerations goes along with a big scale of international disparities in their level and the opposite relationship, which is favourable for the modern branches, can be perceived as well.

Keywords: wage inequality, service sector, modern branches, traditional branches, knowledgebased economy

\section{DOI: $10.7862 /$ rz.2015.mmr.33}

Tekst złożono w redakcji: październik 2013

Przyjęto do druku: wrzesień 2015 